\title{
The Effect of CIO Virtues on CIO Role Effectiveness
}

\author{
Sutirtha Chatterjee \\ U. of Nevada, Las Vegas \\ Suprateek Sarker \\ U. of Virginia \\ ss6wf@comm.virginia.edu
}

\author{
Gregory D. Gregory \\ U. of Nevada, Las Vegas \\ Paul Benjamin Lowry \\ gregory.moody@unlv.edu
}

\begin{abstract}
This paper aims to contribute to the concept of ethical CIO leadership through a distinctive focus on virtue ethics. Our research investigates the theoretical significance of $\mathrm{CIO}$ virtues on two CIO capabilities and their corresponding influence on the CIO's role effectiveness in organizations.
\end{abstract}

\section{Introduction}

In contemporary organizations dealing with the opportunities and challenges of the information age, the role of the CIO (Chief Information Officer) has become paramount $[1,2]$. This is because the CIO is one of the key organizational leaders who oversees the entire IT (Information Technology) for the business organization [2], and is influential in shaping the design, development, and management of IT for greater organizational effectiveness [1].

We argue that the CIO's role has strong ethical underpinnings, as the development, implementation, and management of IT in today's organizations carry weighty ethical connotations [3-7]. One can argue that CIOs, and also other IS leaders, need to engage in "ethical practices and priorities with responsibility, probity, and integrity" because, in many instances, organizational successes or failures depend on how ethically IS are managed and implemented in organizations [3, p. 785]. Furthermore, from an organizational perspective, IT-enabled ethical orientations improve creativity and organizational adaptation and innovation [4].

In general, today's business organizations need to focus on ethical values [8] and organizational leaders have recognized the need for ethics in business and have been taking initiatives to further this cause [9]. Indeed, "ethics is good business" [10, p. 682] because ethical orientations provide "shareholders with insurance-like protection for a firm's relationshipbased intangible assets" [11, p. 777], and thus contribute to an organization's success (ibid).

Although IS leadership has been, and continues to be, an important focus of inquiry [12-14], a review of the existing literature highlights the fact that there is a distinct gap in the inclusion of ethical considerations into aspects of IS leadership. Too often, IS leadership research have been focused on understanding the effects of leadership style, structure, and characteristics on successful IS development, implementation and management. For example, prior IS research has investigated leadership issues such as the shared understanding between $\mathrm{CIO}$ and top management [1]; domain specific CIO characteristics like strategic IT knowledge [2]; and leadership structure [14]. However, the research lacks an explicit investigation on whether certain ethical considerations can be important within the scope of IS leadership. This is all the more surprising, because even within these prior works, the notion of ethics is often implicitly present-from notions of a leader's consideration [14] to leader's help [15] to leaderinitiated empowerment [16].

In light of the general salience of ethical leadership in business organizations, our paper aims to contribute by focusing on how a prominent perspective of ethics - namely, virtue ethics [17] can provide insights into how effective a CIO can be. Given that virtue ethics has been acknowledged to be an important and relevant consideration in current research on leadership [18], our research thus aims to bring explicit ethical considerations to the forefront of IS leadership research, by focusing on the CIO. We build upon prior research, that projects virtue ethics as one of the most powerful theories to analyze and guide organizational leaders and their actions, including the top management team [19, 20].

We specifically argue that certain virtues possessed by the CIO influence two key CIO capabilities-political savviness and communicative ability-that are crucial to the CIO effectively carrying out his/her role. It has been argued that virtues influence or stimulate certain capabilities of entities that possess them [21, 22]. Others concur with this conception, pointing out that Aristotle himself argued that possessing certain virtues are important because they enhance the possessor's capabilities to act in a certain way [23]. Thus, our theoretical framework (Figure 1) is supported in prior research.

In this context, we should also note that this paper answers the call for sustained further work on 
understanding the virtuous characteristics of a leader; that is, to understand what a leader is as opposed to what a leader does [24]. The difference between 'doing' and 'being' is captured by the following distinction: In focusing on 'doing,' one would term a leader who perform 'good actions' to be a good leader. Thus, the focus of such analysis is 'action.' However, in virtue ethics, the focus of analysis is on the character of the person. Specifically, if a leader exhibits good character (i.e., possesses virtues) then it follows that the leader will take 'good actions'. In philosophy, this difference in doing vs being is captured by act-based vs agent-based analysis.

Our paper first reviews the theoretical underpinnings of virtue ethics and delineates key virtues that we posit are relevant to a CIO. We then theorize how these virtues influence two important CIO capabilities, namely CIO political savviness and CIO communicative ability, which in turn affect CIO role effectiveness. Finally, we present our pilot empirical study and outline future research plans and directions.

\section{Background Literature}

Virtue ethics is one of the three classical theories of ethics in philosophy-the other two being deontology [25] and utilitarianism [26]. Virtue ethics draws upon the works of the Greek philosopher, Aristotle [17]. Aristotle described certain characteristics or "virtues" individuals should have: honesty, empathy, and the like. A virtue can be formally defined as "an acquired human quality the possession and exercise of which tends to enable us to achieve those goods which are internal to [community of] practices and the lack of which effectively prevents us from achieving such goods" [27, p. 191]. Virtue ethics leads us to understand that ethical value can be judged from understanding the individual (rooted to a situation, context, or community of practice) who commits the act. Fundamentally, in virtue ethics, goodness is defined as the possession of one or more virtues that are relevant within a community of practice. For example, a good soldier must be courageous (conforming to the soldier's community of practice), whereas a good leader like the CIO, must be motivational (conforming to the leader's community of practice).

As potently argued, personality and situational variables often interact [28], and virtue ethics is defined within this interactionist space [29]. Thus, while virtues can be borne out of personality traits [30], they have an important situationist component, as well [31]. By taking into account both personality and situation, virtue ethics thus provides an interactionist perspective [32]. In contrast to personality traits, the conception of virtues relates to the holism and inclusiveness of our reasoning in response to a particular situation [33]. Acting out of virtue is not similar to performing stereotypical actions following a given personality trait; instead, it is to judge, feel, and act in a situation in a normatively appropriate manner (ibid).

The difference between virtues and personality traits can be better understood by the following example of conscientiousness: Conscientiousness has been long argued to be a personality trait [34] whereas the ethics literature terms it as a virtue [35]. The primary difference between the two is that conscientiousness as a virtue requires the agent to have a deliberate commitment to developing and practicing the virtue because it produces a valuable outcome related to human flourishing and well-being within the context of its practice [36]. Conversely, the conception of conscientiousness as a personality trait does not incorporate this view, as "someone might be conscientious (in the trait sense) for purely instrumental purposes" [30, p. 403] and not have a focus on producing human flourishing and well-being within a specified context (for example, a professional or business context). This is why the virtue of conscientiousness is not the same as the trait of conscientiousness [30].

This is why a focus on virtues adds an interesting dimension to the literature on CIO leadership, much beyond the existing discussion on, for example, leadership personality traits. In fact, some of the virtues discussed in the paper have also found mention in the literature on personality; however, the interpretation of these constructs as virtues is different from the interpretation of them as personality traits.

A focus on virtue ethics is beneficial because virtue ethics forms a plausible way to understand and practice business ethics $[37,38]$. The other prominent ethical theories, deontology [25] and utilitarianism [26], which are often termed as the 'universal approaches' to ethics, often do not provide adequate actionable guidance in business contexts [39]. Instead, they present "an intractable difficulty of applying universalistic moral principles to complex organizational practice" [37, p. 624]. Notably, deontology and utilitarianism are based upon universal ideas that often ignore the context of action. For example, in deontology killing is always 'bad,' but in virtue ethics killing could be understood to be virtuous depending upon one's community of practice and the situation. Thus, a virtuous soldier kills the enemy in the battlefield.

In fact, as business ethics is often concerned with 
"grey areas between good and bad" [40, p. 361], it is helped by the pluralist, flexible approach offered by virtue ethics, especially in situations of extensive social and political changes in the business environment (ibid). Virtue ethics acknowledges that virtues are often malleable enough to fit into the changing business world, as they are often defined within a local community of practice [41]. For example, courage (a virtue) in leading a startup is quite different from courage in leading an established organization. This is why virtue ethics represents a more dynamic way to incorporate ethicality into highly changing business contexts [42]. A set of virtues that we argue are particularly appropriate to CIOs is listed in Table 1.

\section{Table 1. Relevant CIO Virtues}

\begin{tabular}{|c|c|}
\hline Virtue & Definition \\
\hline 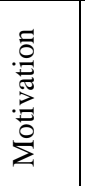 & $\begin{array}{l}\text { This virtue refers to the characteristic of a leader } \\
\text { who stimulates [43] subordinate members and } \\
\text { invites them to be actively involved in the } \\
\text { decision making process [44, p. 712], thus } \\
\text { arousing enthusiasm and optimism [45]. }\end{array}$ \\
\hline 㽦 & $\begin{array}{l}\text { This virtue is concerned with the motivation to } \\
\text { maintain positive relations with others [46]. }\end{array}$ \\
\hline 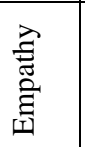 & $\begin{array}{l}\text { This virtue is the ability " to put yourself in the } \\
\text { place of others and treating others as you would } \\
\text { like to be treated" [47] and reflects a concern and } \\
\text { interest for the well-being of others [44] }\end{array}$ \\
\hline 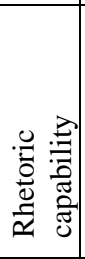 & $\begin{array}{l}\text { This virtue is defined as the ability to consciously } \\
\text { develop "an inventory of phrases and } \\
\text { argumentative devices coupled to a nurtured } \\
\text { understanding of human personality and } \\
\text { motivation so as to better align an audience } \\
\text { towards a specific set of interests without } \\
\text { recourse to threat or compulsion" [48, p. 1667] }\end{array}$ \\
\hline 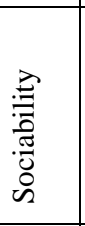 & $\begin{array}{l}\text { This virtue is defined as the possession of social } \\
\text { perceptiveness in terms of complex knowledge } \\
\text { structures of peoples and situations and the } \\
\text { corresponding "ability to apply interpersonal } \\
\text { skills in a socially appropriate manner" [49, p. } \\
\text { 217] }\end{array}$ \\
\hline 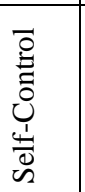 & $\begin{array}{l}\text { This virtue is seen to be related to an ability to } \\
\text { regulate emotions and impulses [50] and exhibit } \\
\text { restraint in situations of crises and upheavals } \\
\text { [51]. }\end{array}$ \\
\hline 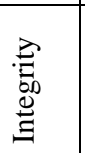 & $\begin{array}{l}\text { This virtue is defined "as a reputation for } \\
\text { trustfulness and honesty of the trusted person" } \\
\text { [52]. }\end{array}$ \\
\hline
\end{tabular}

\section{Model Development}

We now seek to articulate how the virtues in
Table 1 can contribute to our notion of a "good" CIO. Here, two important concepts (which we have alluded to before) require elaboration before we develop our theoretical model: CIO capabilities and $\mathrm{CIO}$ role effectiveness.

There is a clear consensus in prior literature that organizational leaders (like the CIO) should have certain capabilities, and possession of those capabilities would enable them to be effective in carrying out their roles. In the course of our theory development, we draw upon this strong contention in prior literature and understand that, just like other organizational leaders, CIOs too should have certain capabilities which would positively influence their role effectiveness. Using this generally established capabilities $\rightarrow$ role effectiveness framework [2], our focus in this paper is to investigate how a consideration of leadership virtues adds value to the "CIO capabilities $\rightarrow$ CIO role effectiveness framework.” Figure 1 captures our research scope.

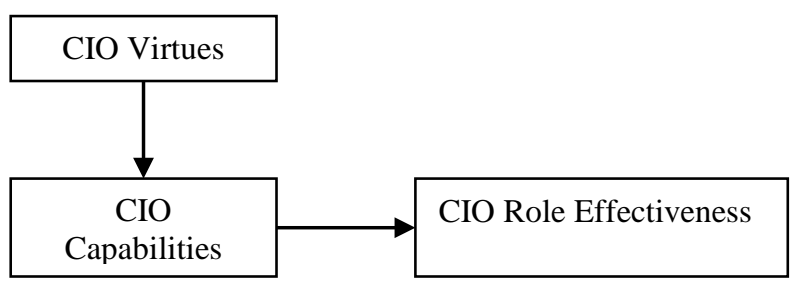

Figure 1. Scope of Research

\subsection{Political savviness}

We particularly focus on two CIO capabilities that we feel are absolutely salient to CIO virtues: CIO political savviness and CIO communicability. These two capabilities have been observed as the "perennial must-haves for all executives” [53, p. 173]. Thus, it is natural to focus on how CIO virtues affect them.

A politically savvy $\mathrm{CIO}$ is defined as one who can "negotiate, influence, and persuade" [2, p. 211]. It is a key quality because a leader needs to be able to negotiate with multiple stakeholders who often have conflicting viewpoints [54], and influence and persuade them to share his/her vision for the organization [55]. In this paper, we theorize that virtues of motivation, warmth, empathy, and rhetoric capability are especially important to the development of such political savvy.

Motivation: In general, a leader (such as the CIO) who is motivating, stimulates others through a variety of techniques to involve them in the decision making process [43]. Such arousal of enthusiasm can be argued to a key factor in the ability to persuade, negotiate, and influence. The importance of motivating effects of leaders is that the subordinate team-members often develop a shared identity 
through trust building and highlighting collective and aspired team goals which can be argued to influence team members toward further achievements [56].

Warmth: We contend that a CIO, who is warm or agreeable, is definitely able to win more friends within an organization because s/he wants to maintain a positive relationship with others [57]. Warmth or agreeableness is especially important for a CIO because this virtue becomes useful in resolving conflicts [58], and maintaining cooperation between groups [57]. The resolution of conflicts is very pertinent to managing IS implementation across organizations partly because such implementations often result in radical organizational changes with implications for various stakeholders who often have conflicting viewpoints [6].

Empathy: We contend that a CIO who is perceived to be empathetic is able to make individuals happy by sharing common emotional elements [52]. Because a happy group of employees and peers can be influenced or persuaded with much greater ease than disgruntled and unhappy employees, we theorize that a CIO who is empathetic has greater ability to engage in successful persuasion, engagement, and negotiation, particularly in cases of interaction with non-IT managers who may have relatively less knowledge of the implications and impact of IT in an organization [2]. It is to be noted that in general, employees and stakeholders respond more to empathetic leaders [59] and we contend that the same should be true for an empathetic CIO.

Rhetoric capability: This virtue is defined as an ability to have "an inventory of phrases and argumentative devices coupled to a nurtured understanding of human personality and motivation so as to better align an audience toward a specific set of interests without recourse to threat or compulsion" [48, p. 1667]. The virtue of rhetoric is advantageous because it helps leaders negotiate with and seek convergence with different stakeholders, who may often have conflicting viewpoints. Often, in an organizational context of IT implementation, the marginalization of individual voices creates problems [6], and the practice of this virtue of rhetoric by the $\mathrm{CIO}$, tends to act against such marginalization, thus inherently leading to the ability to persuade or negotiate more.

It thus becomes evident that this capability of rhetoric for IS leaders such as CIOs becomes pivotal in the ability to successfully negotiate and persuade the stakeholders regarding IT-enabled organizational change. This is because rhetorical means, practiced by the CIO, foster engagement, and thus better persuasion and negotiation, with the organizational stakeholders by "suggesting new relations between technology and culture” [60, p. 41]. Simply put, political savviness can be thought to be the capability to win an argument while keeping others satisfied [43] and the practice of rhetoric contributes to this ability.

Given the arguments in this section, we propose: H1. A CIO's possession of the virtues of motivating (a), warmth (b), empathy (c), and rhetoric skill (d) will positively influence the CIO's political savviness.

\subsection{Communicative ability}

Communicative ability is the "CIO's ability to communicate clearly, persuasively, and in business terms” [2, p. 211]. The importance of communicative ability for success of anyone in a leadership position (including the CIO) has been articulated repeatedly before in prior research $[2,61]$. We posit here that five virtues, namely, empathy, rhetoric capability, socialibility, self-control, and integrity play a particularly crucial role in influencing this capability.

Empathy: As articulated, the virtue of empathy implies that a CIO wins more friends through an image of caring of the CIO. A friend would definitely lend a more sympathetic ear to the CIO than an antagonistic individual. That is, if employees like their CIO because the $\mathrm{CIO}$ is empathetic and caring, then the employees should be more attentive to the leader than one who lack empathy.

Rhetoric capability: By the definition presented above, the virtue of rhetoric implies that the CIO would be able to use a set of argumentative devices to be able to interest different individuals. We thus argue, that such a CIO with an inherently sufficient quality of rhetoric, would be able to gain interest other individuals such as employees and stakeholders and thus be able to convey his/her ideas to such an interested group of audience much better than one with poor rhetoric.

Sociability: This virtue is the possession of complex knowledge structures of peoples and situations and the corresponding "ability to apply interpersonal skills in a socially appropriate manner” [49, p. 217]. In today's organizations, interpersonal skills are clearly required in order to develop a network of relationships [62], which are key to fulfilling CIO roles. We thus contend that this virtue of sociability leads to good communicative capability. A CIO who possesses the sociability virtue will be able to present, for example, an IT implementation plan to a target audience much better and effectively, because s/he has the inherent knowledge of the social structure of the audience.

Self-control: Self-control is defined as the ability to control one's emotions and impulses [50]. Often times, leaders can be in stressful situations and the 
need for self-control arises under those circumstances [43]. In such situations of crises, it becomes imperative that the CIO maintains his/her selfcontrol, otherwise the entire organization could degenerate into the negatives of anxiety and defensiveness [51], which will definitely harm the CIO's ability to convey his or her business message across to the different organization stakeholders in an effective manner. A leader who is often impulsive (and thus does not have a control on emotions and impulses), is judged quite negatively as compared to one who is not, especially in crisis situations [43].

Integrity: This virtue is defined "as a reputation for trustfulness and honesty of the trusted person [52]. Integrity is one of the most frequently cited corporate ethical values [63] and has been called "an essential executive quality" and "an indispensable ingredient” [47, p. 114] for leaders because it influences the ability to articulate to others a rationale for behavior. A CIO who has integrity is often forthright to his/her audience [47] and hence has a greater ability to get his/her message across.

H2. A CIO's possession of the virtues of empathy (a), rhetoric skill (b), sociability (c), self-control (d), and integrity (e) will positively influence the CIO's communicative ability.

\subsection{CIO Role Effectiveness}

The two CIO capabilities discussed abovenamely, political savviness and communicative ability-are theorized to influence the ultimate role effectiveness of the CIO.

Political Savviness: Being politically savvy is a requisite to being effective in political environments such as organizations [64]. This is because political savviness allows individuals to command respect and liking of others; moreover, it also helps them achieve excellence in the organizations in which they work [65]. A CIO is often a part of the top management team, and the political undercurrents between the top management team and the board of directors mostly influence the performance and effectiveness of the top management team [66].

In fact, CIOs are often involved in complex and sensitive matters, such as decision-making on a new technology that may affect the entire organization. [67]. As the harbinger of technological change in an organization, the CIOs ability to correctly comprehend the political consequences of a decision, and accordingly conduct his/her relationship with other members in the organization in a politically correct manner is necessary for the CIO to be effective in his/her role [68]. Therefore:
H3 (a). Political savviness of a CIO positively affects the CIO's role effectiveness.

Communicative ability: The role effectiveness of the CIO is also influenced by the CIO's communicative ability. The theory of transformational leadership [69] argues that charisma is an integral component into being an effective and transformational leader. However, charisma is developed only via a strong communicative ability and the power to effectively convey one's viewpoint [70] Being a transformational leader requires that one is not only inspirational and persuasive, but also can convey these traits in an effective manner [71].

In the case of a CIO, the ever-changing technological landscape requires that the CIO is able to correctly and effectively convey the ramifications of technological advances to the organization and its stakeholders. Unless the CIO can effectively communicate the benefits or possible dangers of a particular technological investment, for example, the organization may end up taking poor technologyrelated decisions, which will further undermine the CIOs ability to effectively lead the technological changes for gaining competitive advantage. Thus, being a strong communicator is important to the CIO being ultimately effective in performing his/her role. Therefore:

H3 (b). Communicative ability of a CIO positively affects the CIO's role effectiveness.

\section{Proposed Methodology}

We followed recent literature in top management journals for the collection of data from C-level executives [72, 73]. Previous survey-based studies have typically suffered from lack of temporal precedence, single informants [74], and CEO changes within the time period of the study [75]. To overcome these limitations, we used multiple informants, collected data at two points in time, and selected firms in which there were no CIO changes for the entire time period of our study. In the first time period, we collected data from the CIO, or equivalent role, and then we collected from the matched informants in the second time period.

In the survey, CIOs were asked to provide contact information for two or three direct reports (i.e., followers). As defined by previous research [76], direct reports are senior managers (from top management teams or TMTs) with whom CEOs share the strategic decision-making process.

To form our sample, we used the FactSet Database (licensed through the PI's university), and it 
was used to identify CIOs and other C-level executives from all national health-related, publicly traded companies headquartered in the United States. We then further used company websites and SEC reporting documents to augment the database with contact information for each individual, for each company in the database. The resultant database contains a panel that consists of 1,012 companies and over 5,000 C-level executives. The companies range from under $\$ 1$ million in annual revenue to $\$ 198$ billion. Our coding and data gathering efforts have resulted in a dataset that contains contact information for 254 of these companies. We note that the focus is currently on health-related companies due to the availability of funds and resources from a universitylevel grant to explore health-related research.

\subsection{Instrument}

The instrument was developed based on previously validated instruments. The sources for each construct are: motivation [77]; warmth [78]; empathy [79]; rhetoric capability [80]; sociability [81]; self-control [82]; integrity [83]; political savviness, communicative ability and role effectiveness [2]. The instrument can be found at this link.

The survey instrument was implemented by means of an online survey engine. This tool allows the researchers to automate data collection by providing the contact list and automating the process. We followed recent guidelines for data collection through an online data collection engine [84].

\subsection{Pilot study}

Prior to engaging in the costly and timely nature of collection from C-level executives, we first conducted a pilot study to verify the nature of our instrument. The purpose of this pilot study was to ascertain that the reliability and validity of the constructs would hold and to identify any problematic questions or wording within the survey. We believe that the validity of the instrument itself is likely generalizable beyond executives. To better understand any problems within the instrument we asked several open-ended questions were added to the end of the survey that allowed subjects to identify any problematic areas that were confusing or were difficult in understanding.

We used Amazon Mechanical Turk to identify and recruit subjects for this pilot study. We used the following restrictions on the subjects: They had to be at least 18 years and old, had to have worked at least 5 years in a full-time position, had to have expert status within the system. We recruit 180 subjects for the pilot study, all of which were compensated \$6 for

their time.

Of the collected sample, 111 (60.3\%) were male, and $69(38.7 \%)$ were female. The average age was 35.05 years $(\mathrm{SD}=9.28$ years). With an average of 5.41 years $(\mathrm{SD}=4.80)$ of work experience with their current organization and 6.36 years $(\mathrm{SD}=5.12)$ of full-time work experience.

\section{Analysis and Results}

Stata 15.1 SE (build 6 June 2018) was used for the analysis of the data. Established measurement and analysis assessment procedures were followed [85]. 31 scores were removed from the analysis, due to missing data.

Test for internal reliability, validity and consistency all revealed that the constructs, and respective items, exhibited proper levels of validity. One exception, the construct of self-control consisted of 13 items, however the analysis revealed that all of the items with reverse coding would not significantly load onto the construct above the .700 threshold, thus they were all removed from the analysis (6 items were retained from the 13).

With that one exception, there were no problems with the convergent or divergent validities, common method bias, or overall fit of the model. The model fit statistics were good to acceptable: $\mathrm{X}^{2}{ }_{1053}=$ $1,777.535 ; \mathrm{X}^{2} / \mathrm{df}=1.609 ; \mathrm{RMSEA}=0.068 ; \mathrm{CFI}=$ 0.863 ; $\mathrm{TLI}=0.853 ; \mathrm{SRMR}=0.111 ; \mathrm{CD}=1.000$. The results of the model are shown in Table 2.

We also report that the predictive power $\left(\mathrm{R}^{2}\right)$ of our model was as follows: political savviness (0.321); communicative ability (0.116); and role effectiveness (0.359). The predictive power of political savviness and role effectiveness were quite acceptable, with only moderate success for communicative ability.

To summarize the results, $\mathrm{H} 1$ received partial support. Empathy (H1c) and rhetorical skills (H1d) were both significant predictors of political savviness. However, motivation (H1a) and warmness (H1b) were not.

Table 2. Summary of results

\begin{tabular}{|l|l|r|r|r|r|}
\hline H\# & Relationship & Coef. & SE & $\mathbf{Z}$ & $\mathbf{p}$ \\
\hline 1a & Mot $\rightarrow$ Savv & .136 & .118 & 1.16 & .248 \\
\hline 1b & Warm $\rightarrow$ Savv & .165 & .109 & 1.51 & .132 \\
\hline 1c & Emp $\rightarrow$ Savv & .306 & .109 & 2.82 & .005 \\
\hline 1d & Rhet $\rightarrow$ Savv & .338 & .091 & 3.73 & .000 \\
\hline 2a & Emp $\rightarrow$ Comm & .201 & .105 & 1.91 & .055 \\
\hline 2b & Rhet $\rightarrow$ Comm & .284 & .103 & 2.75 & .006 \\
\hline 2c & SelfC $\rightarrow$ Comm & -.093 & .095 & -0.97 & .330 \\
\hline 2d & Integ $\rightarrow$ Comm & -.064 & .120 & -0.53 & .593 \\
\hline 2e & Social $\rightarrow$ Com & .051 & .103 & 0.49 & .621 \\
\hline 3a & Savv $\rightarrow$ Effct & .431 & .082 & 5.28 & .000 \\
\hline 3b & Comm $\rightarrow$ Effct & .332 & .089 & 3.73 & .000 \\
\hline \multicolumn{7}{|c|}{ H2 also received partial support. Empathy (H2a) }
\end{tabular}


and rhetorical skill (H2b), again, were significant predictors of communicative ability. However, selfcontrol (H2c), integrity (H2d) and sociability (H2e) were not significant predictors of communicative ability. Whereas, the insignificant predictors for $\mathrm{H} 1$ were nearing significance, the predictors for $\mathrm{H} 2$ were not, and were quite small.

H3 received complete support. Savviness and communicative ability were both significant predictors of role effectiveness.

The results thus support the importance of empathy and rhetoric skills as significant values for subjects to have in regards for improving skills of leaders, specifically, political savviness and communicative ability, which both in turn improve the effective role within the context of our pilot study.

\section{Discussion}

Our results indicate that ethical values can in fact impact the leadership capabilities within our pilot sample, and that these capabilities can positively impact the overall effectiveness of the leader in their role. We note that the only values that were effective in our sample were empathy and rhetoric skill, and no other proposed ethical values. This may have been a function of our sample. Given that our sample did not consist of leaders, but regular workers, the values of empathy and rhetoric skill may be more universal and work with lower levels of employees and working with their colleagues. Thus, the ability of motivation, warmth, self-control, integrity and sociability may be important for those in leadership roles, our sample simply did not consist of these types of roles.

The purpose of the pilot study was not to test the validity of the model per se and whether it would hold as expected, but rather to test the reliability and validity of the instrument. Our results do show that the instrument worked for all constructs, with some minor changes needed only for self-control. However, the results do show, that even for nonleaders, that the ethical values are important predictors of skills needed to be more effective in their current roles.

We now explicitly turn to the potential contribution that our pilot, and eventual data collection can have to the IS literature.

\subsection{Contribution to research}

This study potentially contributes on multiple fronts. First, the paper delineates a suitable list of virtues and how they are related to CIO's capability and thus ultimately influence a CIO's role effectiveness. Especially within the CIO literature, there has been little prior understanding of ethical leadership, and more so for virtue-based leadership. While the CEO and leadership literature has certainly discussed the topic of ethical leadership extensively and have articulated certain virtues which are characteristics of such leaders, the actual theoretical mechanism of the relevance of these virtues has mostly escaped scrutiny. This paper thus contributes by its virtue-based theorization of a "good" CIO which can also be extended to other organizational leaders like the CEO.

Second, the paper goes beyond the existing literature understanding the role of personality and physical traits in leadership, which are inherently descriptive and thus been often characterized in prior research as morally neutral [86]. Through the development of an ethical value system in the form of a core set of virtues, this paper provides a normative lens to analyze CIO characteristics, which is more pertinent in understanding notions of organizational level ethical behavior such as corporate social responsibility. It is to be noted that it is the leaders of an organization who stimulate its ethical behavior [87], and so an analysis of values that should characterize a good leader increases its relevance to organization-level ethics. While personality and physical traits are constant [88], virtues can be developed and modified within a community of practice [27, 41], and so they form effective normative prescriptions for developing good leader characteristics.

Finally, on a general level, it brings forth the importance of infusing ethics to business organizations, a notion especially relevant in the context of the well-publicized ethical scandals (e.g., Enron, MCI, Adelphia). The paper answers this call by providing a justification on why virtue ethics is important to business organizations and contributes by focusing on the virtue characteristics of CIOs that make them effective organizational leaders.

\subsection{Future implications}

The paper raises numerous implications for future research. First, the theoretical model provided in this paper can give rise to numerous empirical studies in order to test the model across various organizations, contexts, countries and cultures. The results of those empirical testing would enable us to gain a deeper understanding of the nature of "good" CIOs.

Second, moving beyond the scope of CIOs, it would be interesting to extend or modify this model in terms of the top management (e.g., CEO) excluding the CIO. This would necessarily mean that 
a core set of CEO capabilities and roles (which have been discussed in numerous previous works) be theoretically linked to the notion of CEO virtues. Again, this is fruitful fodder (both theoretical and empirical) for future research.

Third, future research could investigate how organizational leaders develop the virtues mentioned here. As noted earlier, development and practice of virtues takes place within a community of practice [27] and hence it would be a fruitful endeavor to research into normative techniques (within the organizational community of practice) that can develop and sustain such virtues of organizational leaders.

Fourth, this paper can also energize future researchers to critique or modify the arguments presented here, by presenting alternate ethical viewpoints to further this academic discussion.

\section{Conclusion}

To conclude, we believe that there is a lot to be known about the notion of ethical IS leaders. We hope that our paper here contributes by to this scope of inquiry and by raising the call for future research to further this line of thought along different directions. Also, our intent was to be a starting point of theoretically infusing virtue ethics into notion of ethical IS leaders, and we hope that future research will continue to contribute to this academic discussion.

\section{References}

[1] D. S. Preston, E. Karahanna, and F. Rowe, "Development of Shared Understanding between the Chief Information Officer and Top Management Team in U.S. And French Organizations: A Cross-Cultural Comparison," IEEE Transactions on Engineering Management vol. 53, pp. 191-206, 2006.

[2] D. H. Smaltz, V. Sambamurthy, and R. Agarwal, "The Antecedents of Cio Role Effectiveness in Organizations:An Empirical Study in the Healthcare Sector," Engineering Management, IEEE Transactions on, vol. 53, pp. 207-222, 2006.

[3] A. Bryant, F. Land, and J. L. King, "Editors' Introduction," JAIS, vol. 10, pp. 782-786, 2009.

[4] S. Chatterjee, G. D. Moody, P. B. Lowry, S. Chakraborty, and A. Hardin, "Strategic Relevance of Organizational Virtues Enabled by Information Technology in Prganizational Innovation," Journal of Management Information Systems, vol. 32, pp. 158196, 2015.

[5] S. Chatterjee, S. Sarker, and M. Fuller, "A Deontological Approach to Designing Ethical Collaboration," Journal of the Association for Information Systems, vol. 10, pp. 138-169, 2009a.

[6] S. Chatterjee, S. Sarker, and M. Fuller, "Ethical
Information Systems Development: A Baumanian Postmodernist Perspective," Journal of the Association for Information Systems, vol. 10, pp. 787815, 2009b.

[7] J. Mingers and G. Walsham, "Toward Ethical Information Systems: The Contribution of Discourse Ethics," MIS Quarterly, vol. 34, pp. 833-854, 2010.

[8] R. A. Giacalone. (2006) New Ethics in the Office,. BizEd. 24.

[9] Y. Shin, "Ceo Ethical Leadership, Ethical Climate, Climate Strength, and Collective Organizational Citizenship Behavior," Journal of Business Ethics, vol. 108, pp. 299-312, 2012.

[10] M. J. Culnan and C. C. Williams, "How Ethics Can Enhance Organizational Privacy: Lessons from the Choicepoint and Tjx Data Breaches," MIS Quarterly, vol. 33, pp. 673-687, 2009.

[11] P. C. Godfrey, "The Relationship between Corporate Philanthropy and Shareholder Wealth: A Risk Management Perspective," Academy of Management Review, vol. 30, pp. 777-798, 2005.

[12] C. P. Armstrong and V. Sambamurthy, "Information Technology Assimilation in Firms: The Influence of Senior Leadership and It Infrastructures," Information Systems Research, vol. 10, pp. 304-327, December 1, 19991999.

[13] S. Faraj and V. Sambamurthy, "Leadership of Information Systems Development Projects," Engineering Management, IEEE Transactions on, vol. 53, pp. 238-249, 2006.

[14] G.-W. Bock, W.-L. Ng, and Y. Shin, "The Effect of a Perceived Leader's Influence on the Motivation of the Members of Nonwork-Related Virtual Communities," Engineering Management, IEEE Transactions on, vol. 55, pp. 292-303, 2008.

[15] R. Cordero and G. F. Farris, "Administrative Activity and the Managerial Development of Technical Professionals," Engineering Management, IEEE Transactions on, vol. 39, pp. 270-276, 1992.

[16] D. S. Preston, D. Chen, and D. E. Leidner, "Examining the Antecedents and Consequences of Cio Strategic Decision-Making Authority: An Empirical Study," Decision Sciences, vol. 39, pp. 605-642, 2008.

[17] Aristotle, Nicomachean Ethics (Trans. Terence Irwin). Indianapolis: Hackett Publishing Co, 1985.

[18] B. McKenna, D. Rooney, and K. B. Boal, "Wisdom Principles as a Meta-Theoretical Basis for Evaluating Leadership," The Leadership Quarterly, vol. 20, pp. 177-190, 2009.

[19] P. P. Heugens, M. Kaptein, and J. Van Oosterhout, "Contracts to Communities: A Processual Model of Organizational Virtue," Journal of Management Studies, vol. 45, pp. 100-121, 2008.

[20] H. van Dijk, M. van Engen, and J. Paauwe, "Reframing the Business Case for Diversity: A Values and Virtues Perspective," Journal of Business Ethics, vol. 111, pp. 73-84, 2012.

[21] A. Bertland, "Virtue Ethics in Business and the Capabilities Approach," Journal of Business Ethics, vol. 84, pp. 25-32, 2009.

[22] R. Buchholz and S. Rosenthal, "Toward a 
Contemporary Conceptual Framework for Stakeholder Theory," Journal of Business Ethics, vol. 58, pp. 137148, 2005.

[23] M. Merritt, "Virtue Ethics and Situationist Personality Psychology," Ethical Theory and Moral Practice, vol. 3, pp. 365-383, 2000.

[24] T. A. Wright and J. Goodstein, "Character Is Not "Dead" in Management Research: A Review of Individual Character and Organizational-Level Virtue," Journal of Management, vol. 33, pp. 928-958, December 1, 20072007.

[25] I. Kant, Ethical Philosophy: Grounding for the Metaphysics of Morals (Trans. James W. Ellington). Indianapolis: Hackett, 1804/1994.

[26] J. S. Mill, Utilitarianism Indianapolis, IN: Hackett Publishing, 1861/1979.

[27] A. MacIntyre, After Virtue. Notre Dame, IN.: Notre Dame Press, 1985.

[28] L. Ross and R. E. Nisbett, The Person and the Situation: Perspectives of Social Psychology. New York: McGraw-Hill, 1991.

[29] C. Miller, "Social Psychology and Virtue Ethics," The Journal of Ethics, vol. 7, pp. 365-392, 2003.

[30] D. J. Ozer and V. Benet-Martínez, "Personality and the Prediction of Consequential Outcomes," Annual Review of Psychology, vol. 57, pp. 401-421, 2006/01/01 2006.

[31] G. R. Weaver, "Virtue in Organizations: Moral Identity as a Foundation for Moral Agency," Organization Studies, vol. 27, pp. 341-368, March 1, 20062006.

[32] W. Fleeson, "Moving Personality Beyond the PersonSituation Debate," Current Directions in Psychological Science, vol. 13, pp. 83-87, April 1, 20042004.

[33] R. Kamtekar, "Situationism and Virtue Ethics on the Content of Our Character," Ethics, vol. 114, pp. 458491, 2004.

[34] R. R. McCrae and P. T. Costa, "Validation of the FiveFactor Model of Personality across Instruments and Observers," Journal of Personality and Social Psychology, vol. 52, pp. 81-90, 1987.

[35] H. Battaly, "Virtue Epistemology," Philosophy Compass, vol. 3, pp. 639-663, 2008.

[36] R. Crisp, "Virtue Ethics and Virtue Epistemology," Metaphilosophy, vol. 41, pp. 22-40, 2010.

[37] J. Collier, "Theorising the Ethical Organization," Business Ethics Quarterly, vol. 8, pp. 621-654, 1998.

[38] E. M. Hartman, "The Role of Character in Business Ethics," Business Ethics Quarterly, vol. 8, pp. 547559, 1998.

[39] J. T. Whetstone, "How Virtue Fits within Business Ethics," Journal of Business Ethics, vol. 33, pp. 101114, 2001.

[40] G. Flynn, "The Virtuous Manager: A Vision for Leadership in Business," Journal of Business Ethics, vol. 78, pp. 359-372, 2008.

[41] R. C. Solomon, "Victims of Circumstances? A Defense of Virtue Ethics in Business," Business Ethics Quarterly, vol. 13, pp. 43-62, 2003.

[42] S. Arjoon, "Virtue Theory as a Dynamic Theory of
Business," Journal of Business Ethics, vol. 28, pp. 159-178, 2000.

[43] S. A. Kirkpatrick and E. A. Locke, "Leadership: Do Traits Matter?," The Executive, vol. 5, pp. 48-60, 1991.

[44] S. Sarin and C. McDermott, "The Effect of Team Leader Characteristics on Learning, Knowledge Application, and Performance of Cross-Functional New Product Development Teams," Decision Sciences, vol. 34, pp. 707-739, 2003.

[45] B. M. Bass, D. I. Jung, B. J. Avolio, and Y. Berson, "Predicting Unit Performance by Assessing Transformational and Transactional Leadership," JAP, vol. 88, pp. 207-218, 2003.

[46] J. S. Wiggins and T. P. D., "Personality Structure: The Return of the Big Five," in Handbook of Personality Psychology, S. R. Briggs, R. Hogan, and W. H. Jones, Eds., ed San Diego, CA: Academic Press, 1997.

[47] P. E. Murphy, "Character and Virtue Ethics in International Marketing: An Agenda for Managers, Researchers and Educators," Journal of Business Ethics, vol. 18, pp. 107-124, 1999.

[48] R. Holt, "Principals and Practice: Rhetoric and the Moral Character of Managers," Human Relations, vol. 59, pp. 1659-1680, December 1, 20062006.

[49] M. Schneider, "A Stakeholder Model of Organizational Leadership," Organization Science, vol. 13, pp. 209-220, 2002.

[50] B. Dyck and R. Kleysen, "Aristotle's Virtues and Management Thought: An Empirical Exploration of an Integrative Pedagogy," Business Ethics Quarterly, vol. 11, pp. 561-574, 2001.

[51] Q. N. Huy, "Emotional Capability, Emotional Intelligence, and Radical Change," The Academy of Management Review, vol. 24, pp. 325-345, 1999.

[52] R. Chun, "Ethical Character and Virtue of Organizations: An Empirical Assessment and Strategic Implications," Journal of Business Ethics, vol. 57, pp. 269-284, 2005.

[53] E. Karahanna and R. T. Watson, "Information Systems Leadership," Engineering Management, IEEE Transactions on, vol. 53, pp. 171-176, 2006.

[54] T. V. Mumford, M. A. Campion, and F. P. Morgeson, "The Leadership Skills Strataplex: Leadership Skill Requirements across Organizational Levels," The Leadership Quarterly, vol. 18, pp. 154-166, 2007.

[55] G. Yukl, Leadership in Organizations (5th Edition). Englewood Cliffs, NJ: Prentice-Hall, 2002.

[56] A. Joshi, M. B. Lazarova, and H. Liao, "Getting Everyone on Board: The Role of Inspirational Leadership in Geographically Dispersed Teams," Organization Science, vol. 20, pp. 240-252, 2009.

[57] W. G. Graziano and N. Eisenberg, "Agreeableness: A Dimension of Personality," in Handbook of Personality Psychology, R. Hogan, J. A. Johnson, and S. R. Briggs, Eds., ed San Diego, CA: Academic Press, 1997, pp. 795-824.

[58] L. A. Jensen-Campbell and W. G. Graziano, "Agreeableness as a Moderator of Interpersonal Conflict," Journal of Personality, vol. 69, pp. 323362, 2001. 
[59] D. J. McAllister and G. A. Bigley, "Work Context and the Definition of Self: How Organizational Care Influences Organization-Based Self-Esteem," AMJ, vol. 45, pp. 894-904, 2002.

[60] M. J. Salvo, "Rhetorical Action in Professional Space: Information Architecture as Critical Practice," Journal of Business and Technical Communication, vol. 18, pp. 39-66, January 1, 20042004.

[61] T. R. Kayworth and D. E. Leidner, "Leadership Effectiveness in Global Virtual Teams," J. Manage. Inf. Syst., vol. 18, pp. 7-40, 2002.

[62] G. DeSanctis, J. T. Glass, and I. M. Ensing, "Organizational Designs for R\&D," The Academy of Management Executive (1993), vol. 16, pp. 55-66, 2002.

[63] L. K. Trevino, M. Brown, and L. P. Hartman, "A Qualitative Investigation of Perceived Executive Ethical Leadership: Perceptions from inside and Outside the Executive Suite," Human Relations, vol. 56, pp. 5-37, January 1, 20032003.

[64] G. R. Ferris, D. C. Treadway, P. L. Perrewé, R. L. Brouer, C. Douglas, and S. Lux, "Political Skill in Organizations," Journal of Management, vol. 33, pp. 290-320, 2007.

[65] G. Ferris and S. Davidson, Political Skill at Work: Impact on Work Effectiveness: Nicholas Brealey Publishing, 2011.

[66] T. Shin, "Ceo Compensation and Shareholder Value Orientation among Large Us Firms," The Economic and Social Review, vol. 43, pp. 535-559, 2012.

[67] J. W. Weiss and D. Anderson Jr, "Cios and It Professionals as Change Agents, Risk and Stakeholder Managers: A Field Study," Engineering management journal, vol. 16, pp. 13-18, 2004.

[68] G. S. Dawson and R. T. Watson, "Uncovering and Testing Archetypes of Effective Public Sector Cios," ACM Trans. Manage. Inf. Syst., vol. 2, pp. 1-19, 2011.

[69] B. M. Bass, Leadership and Performance Beyond Expectations. New York: Free Press, 1985.

[70] S. J. Holladay and W. T. Coombs, "Communicating Visions: An Exploration of the Role of Delivery in the Creation of Leader Charisma," Management Communication Quarterly, vol. 6, pp. 405-427, 1993.

[71] S. Scott-Halsell, S. R. Shumate, and S. Blum, "Using a Model of Emotional Intelligence Domains to Indicate Transformational Leaders in the Hospitality Industry," Journal of Human Resources in Hospitality \& Tourism, vol. 7, pp. 99-113, 2007.

[72] P. Herrmann and S. Nadkarni, "Managing Strategic Change: The Duality of Ceo Personality," Strategic Management Journal, vol. 35, pp. 1318-1342, 2014.

[73] C. Sirén, P. C. Patel, and J. Wincent, "How Do Harmonious Passion and Obsessive Passion Moderate the Influence of a Ceo's Change-Oriented Leadership on Company Performance?," The Leadership Quarterly, vol. 27, pp. 653-670, 2016.

[74] Z. Simsek, C. Heavey, and J. J. F. Veiga, "The Impact of Ceo Core Self-Evaluation on the Firm's Entrepreneurial Orientation," Strategic Management Journal, vol. 31, pp. 110-119, 2010.

[75] B. R. Agle, N. J. Nagarajan, J. A. Sonnenfeld, and D.
Srinivasan, "Does Ceo Charisma Matter? An Empirical Analysis of the Relationships among Organizational Performance, Environmental Uncertainty, and Top Management Team Perceptions of Ceo Charisma," Academy of Management Journal, vol. 49, pp. 161-174, 2006.

[76] D. C. Hambrick and P. A. Mason, "Upper Echelons: The Organization as a Reflection of Its Top Managers," The Academy of Management Review, vol. 9, pp. 193-206, 1984.

[77] T. R. Hinkin and J. B. Tracey, "The Relevance of Charisma for Transformational Leadership in Stable Organizations," Journal of Organizational Change Management, vol. 12, pp. 105-119, 1999.

[78] L. R. Goldberg, "An Alternative" Description of Personality": The Big-Five Factor Structure," Journal of Personality and Social Psychology, vol. 59, p. 1216, 1990.

[79] R. Mahsud, G. Yukl, and G. Prussia, "Leader Empathy, Ethical Leadership, and Relations-Oriented Behaviors as Antecedents of Leader-Member Exchange Quality," Journal of Managerial Psychology, vol. 25, pp. 561-577, 2010.

[80] J. E. Baur, B. Parker Ellen, M. R. Buckley, G. R. Ferris, T. H. Allison, A. F. McKenny, and J. C. Short, "More Than One Way to Articulate a Vision: A Configurations Approach to Leader Charismatic Rhetoric and Influence," The Leadership Quarterly, vol. 27, pp. 156-171, 2016/02/01/ 2016.

[81] J. M. Cheek and A. H. Buss, "Shyness and Sociability," Journal of Personality and Social Psychology, vol. 41, pp. 380-389, 1981.

[82] J. P. Tangney, R. F. Baumeister, and A. L. Boone, "High Self-Control Predicts Good Adjustment, Less Pathology, Better Grades, and Interpersonal Success," Journal of Personality, vol. 72, pp. 271-324, 2004.

[83] R. C. Mayer and J. H. Davis, "The Effect of the Performance Appraisal System on Trust for Management: A Field Quasi-Experiment," Journal of Applied Psychology, vol. 84, p. 123, 1999.

[84] P. B. Lowry, J. D’Arcy, B. Hammer, and G. D. Moody, "'Cargo Cult' Science in Traditional Organization and Information Systems Survey Research: A Case for Using Nontraditional Methods of Data Collection, Including Mechanical Turk and Online Panels," Journal of Strategic Information Systems, vol. 25, pp. 232-240, 2016.

[85] D. Gefen, E. E. Rigdon, and D. Straub, "Editor's Comments: An Update and Extension to Sem Guidelines for Administrative and Social Science Research," MIS Quarterly, vol. 35, pp. iii-xiv, 2011.

[86] M. J. Cawley, J. E. Martin, and J. A. Johnson, "A Virtues Approach to Personality," Personality and Individual Differences, vol. 28, pp. 997-1013, 2000.

[87] G. Moore and R. Beadle, "In Search of Organizational Virtue in Business: Agents, Goods, Practices, Institutions and Environments," Organization Studies, vol. 27, pp. 369-389, March 1, 20062006.

[88] R. R. McCrae and P. T. Costa, "Personality Trait Structure as a Human Universal," American Psychologist, vol. 52, pp. 509-516, 1997. 